\title{
Development of a Water Quality Index (WQI) of an Artificial Aquatic Ecosystem in Mexico
}

\author{
H. Rubio-Arias ${ }^{1}$, J. M. Ochoa-Rivero ${ }^{2 *}$, R. M. Quintana ${ }^{1}$, R. Saucedo-Teran ${ }^{3}$, R. C. Ortiz-Delgado ${ }^{2}$, \\ N. I. Rey-Burciaga ${ }^{2}$, J. R. Espinoza-Prieto ${ }^{1}$ \\ ${ }^{1}$ College of Animal Husbandry and Ecology, The Autonomous University of Chihuahua, Chihuahua, Mexico; ${ }^{2}$ College of Animal \\ Husbandry and Ecology, The Autonomous University of Chihuahua, Chihuahua, Mexico; ${ }^{3}$ National Institute of Forestry, Agriculture \\ and Livestock Production in Mexico, Chihuahua, Mexico. \\ Email: rubioa1105@hotmail.com,rquintan@uach.mx, chuy-8-a@hotmail.com, aguila_ortiz1@hotmail.com, ivet.rey7@gmail.com, \\ saucedotra@hotmail.com
}

Received August $14^{\text {th }}, 2013$; revised September $15^{\text {th }}, 2013$; accepted October $14^{\text {th }}, 2013$

Copyright (C) 2013 H. Rubio-Arias et al. This is an open access article distributed under the Creative Commons Attribution License, which permits unrestricted use, distribution, and reproduction in any medium, provided the original work is properly cited.

\begin{abstract}
A Water Quality Index (WQI) is a simple numeric expression reflecting the quality of water in any ecosystem at a given time. The objective of this study was to develop a WQI for the man-made dam Francisco I. Madero located in Chihuahua, Mexico. Eight points were randomly selected in the dam area and at each point water samples were collected monthly from March 2011 to February 2012 at three depths; $0.30 \mathrm{~m}, 5 \mathrm{~m}$ and $10 \mathrm{~m}$. The following physical-chemical variables were measured: potential hydrogen $(\mathrm{pH})$, electrical conductivity $(\mathrm{EC})$, dissolved oxygen (DO), temperature (T), turbidity, total dissolved solids (TDS), total hardness (TH) and chlorides $\left(\mathrm{Cl}^{-}\right)$. In a first step for data analysis, an analysis of variance (ANOVA) was performed for each variable considering a factorial treatment design $12 \times 3$ in which factor A was the month with 12 levels (sampling months) and factor B was the depth with three levels $(0.30 \mathrm{~m}, 5$ $\mathrm{m}$ and $10 \mathrm{~m})$. In a second statistical step, the WQI was calculated for each month only for the surface sampling $(0.30 \mathrm{~m})$ and the resulting value was classified under three categories; $<2.0$ as poor water, in a range of 2.0 to 2.5 as good water and, $>2.5$ as excellent water. The results showed the following ranges for single variables: $\mathrm{pH}$ of $7.63-10.65, \mathrm{EC}$ of $190-320 \mu \mathrm{S} \cdot \mathrm{cm}^{-1}$, DO of $1.30-12.1 \mathrm{mg} \cdot \mathrm{L}^{-1}$, T of $11.30^{\circ} \mathrm{C}-30^{\circ} \mathrm{C}$, Turbidity of $0-1,120 \mathrm{NTU}$, TDS of $170-220$ $\mathrm{mg} \cdot \mathrm{L}^{-1}$, TH of $240-900 \mathrm{mg} \cdot \mathrm{L}^{-1}$ and $\mathrm{Cl}^{-}$of $7.28-7034 \mathrm{mg} \cdot \mathrm{L}^{-1}$. The calculated WQI demonstrated that water quality varies seasonally and was classified as poor in the rainy season to good in winter season. We conclude that in general the water from the dam is acceptable and suitable for ecological and a broad spectrum of other purposes.
\end{abstract}

Keywords: Water Quality; Index; Chihuahua; Mexico; Ecology; Contamination

\section{Introduction}

Artificial water reservoirs are important for domestic activities, industry, agriculture and livestock production, especially in arid and semi-arid zones. Nowadays, anthropogenic activities have contributed to pollution of these ecosystems. Consequently, it is necessary to employ new tools and methodologies to determine the level of pollution of any ecosystem at a given time. One alternative is the estimation of the water quality index (WQI), which is a simple arithmetic tool to assess water quality [1-6]. Calculating the WQI is based on the integration of physical-chemical-biological variables to generate a single value as an indicator of water quality [7-9]. In the

${ }^{*}$ Corresponding author. mid-1960s Horton [10] developed the first WQI and since then this tool has been used to determine water quality in rivers [11], lakes [12], dams [13], and groundwater [14]. In addition, some variations of the WQI have been adjusted to potable water, recreational water and fisheries [15]. In some cases, the analysis has involved modulation or forecast because of easy interpretation of results [16]. In some cases WQI values allow for identifying pollution variables, consequently for recommending preventive actions in the water ecosystem [17]. This methodology had been used in countries, such as Argentina [18], Brazil [19], Spain [20], the United States [21], Iran [22] and Malawi [23].

In the case of Mexico, there have been some studies concerning water pollution in the Conchos watershed, the 
most important watershed in the State of Chihuahua [24] as well as in tributaries like the San Pedro River [25]. The studies detected varying levels of pollution in the rivers and other water ecosystems in Chihuahua [26-28]. For instance, Gutierrez et al. [29] determined contamination levels in the San Pedro River and the Francisco I Madero Dam. The dam, which is ranked as the third largest in the State of Chihuahua, provides waters to the communities in south-center Chihuahua and is a tourist and recreational attraction. The objective of this study was to develop a WQI for the water of the Francisco I. Madero Dam and to assess the spatial variability of the parameters. The results will allow inhabitant sand the authorities to differentiate pollution levels to know water quality and to implement corrective or preventive actions.

\section{Materials and Methods}

The study was carried out at the Francisco I. Madero Dam situated in the Municipality of Rosales, Chihuahua, Mexico. The dam is commonly known as "Las Virgenes" and is located between latitude $28^{\circ} 09^{\prime} 58.82^{\prime \prime} \mathrm{N}$ and longi- tude $105^{\circ} 37^{\prime} 43.95^{\prime \prime} \mathrm{W}$ with an altitude $1250 \mathrm{~m}$ (Figure 1). The water reservoir is about $80 \mathrm{~km}$ from the city of Chihuahua and its main source is the San Pedro River, which is a tributary of the Conchos River. The dam has a capacity of $424 \mathrm{Mm}^{3}$ and is considered the third most important dam in the State of Chihuahua [30,31]. The waters come under the authority of Irrigation District 005 (ID005), which is the most important in the State and one of the largest in Mexico. The region has a semiarid climate with a maximum temperature of $41.7^{\circ} \mathrm{C}$ in summer and a minimum of $-14.1^{\circ} \mathrm{C}$ in winter. Average annual precipitation is $294.7 \mathrm{~mm}$ with about 61 days of rain. Dominant winds are from the southwest. The dam is located between the great northern plains and the Sierra Madre Occidental mountain range [24,30,32].

\subsection{Water Sampling}

Water samples were obtained randomly. In a first step, with the help of a satellite image of the dam, the area was divided into $1-\mathrm{km}^{2}$ quadrants using the geographic software Google ${ }^{\mathrm{TM}}$ Earth. In a second step eight quadrants

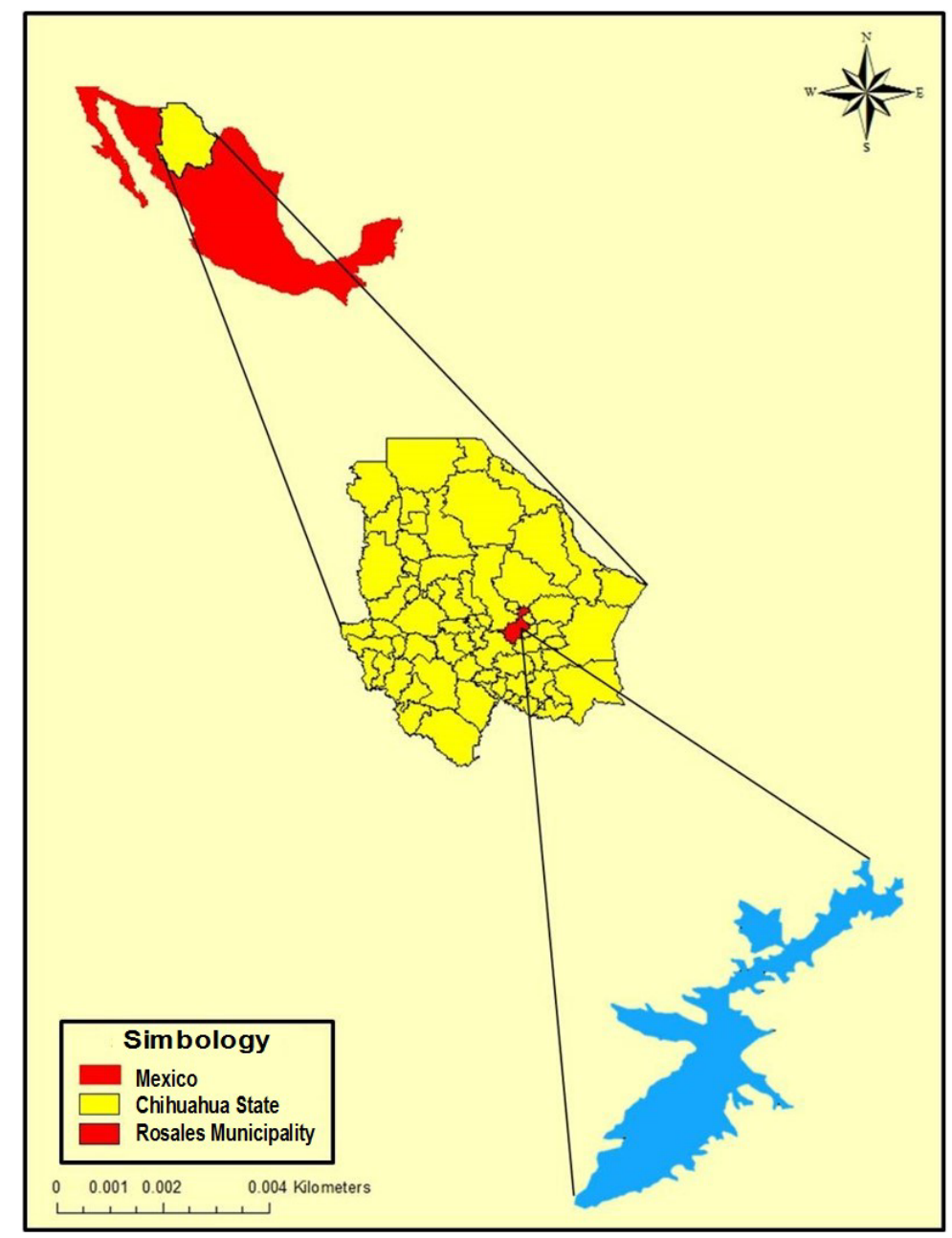

Figure 1. Location of the Francisco I. Madero Dam in Chihuahua, Mexico. 
were randomly designated as sampling sites. In each sampling site, during the period of March 2011 to February 2012 monthly water samples were collected at three depths; $0.30 \mathrm{~m}, 5 \mathrm{~m}$ and $10 \mathrm{~m}$. Water samples were obtained in 1-liter containers that were washed, sterilized and properly identified. Water samples at $5 \mathrm{~m}$ and $10 \mathrm{~m}$ were obtained with a Van Dorn bottle (Plano $\left.{ }^{\mathrm{TM}}\right)$. A total of 288 water samples were obtained as a product of 12 months of sampling, eight sampling sites and three depths $(12 \times 8 \times 3)$. Once the samples were obtained they were kept on ice at $4^{\circ} \mathrm{C}$ to be transported to the laboratory of the College of Animal Husbandry and Ecology of the Autonomous University of Chihuahua for further analysis. The water samples were collected in accordance with official Mexican standards [33].

\subsection{Physical-Chemical Analysis}

The following variables were evaluated in situ; potential hydrogen $(\mathrm{pH})$, electrical conductivity (EC) and temperature $(\mathrm{T})$ were measured with a Hanna instruments ${ }^{\mathrm{TM}}$ (a waterproof HI-9146 pH/CE/temp. model). Dissolved oxygen (DO) was determined with a portable $\operatorname{Hach}^{\mathrm{TM}}$ model 156 , while turbidity was estimated with a turbid meter HI-93703C. Total dissolved solids (TDS) were calculated with an Oakton model waterproof/TDS/Test low. The $\mathrm{pH}$ level is reported in $\mathrm{pH}$ units, $\mathrm{EC}$ in $\mu \cdot \mathrm{Sm}^{-1}$, $\mathrm{T}$ in Celsius degree $\left({ }^{\circ} \mathrm{C}\right)$, DO in $\mathrm{mg} \cdot \mathrm{L}^{-1}$, turbidity is reported in nephelometric turbidity units (NTU) and TDS in $\mathrm{mg} \cdot \mathrm{L}^{-1}$. The following variables were evaluated in the laboratory: total hardness $(\mathrm{TH})$ was estimated by EDTA titration and the results are expressed in $\mathrm{mg} \cdot \mathrm{L}^{-1}$ while Chlorides $\left(\mathrm{Cl}^{-}\right)$were determined using the Mohr method. These parameters were analyzed following Mexican government standards [34-40].

\subsection{Statistical Analysis and WQI Calculation}

Data analysis was carried out in two steps. In the first, an analysis of variance (ANOVA) was performed for each variable. In the second step WQI was calculated. The ANOVA for each variable considered a factorial treatment design $12 \times 3$ where factor $\mathrm{A}$ was the sampling month, with 12 levels (the sampling months) and factor B was depth, with three levels $(0.30 \mathrm{~m}, 5 \mathrm{~m}$ and $10 \mathrm{~m})$. Hence, the effects of month, depth and month-depth interaction were identified. All statistical analyses were performed using a level of significance of $0.05(\alpha=0.05)$. When the interaction is significant, an interaction graph is shown, while a main factor graph is shown for nonsignificant interactions.

The WQI was calculated following the methodology recommended by Rubio et al. [28] which consists of three steps and was computed only for the depth of 0.30 $\mathrm{m}$. In the first step, each parameter was assigned a specific weight (Wi) in a range of 1 to 4 according to the level of importance of the parameter in determining water quality. Four represented the most important and one the least important. The Wi values were assigned as follows: $\mathrm{pH}, \mathrm{OD}$ and $\mathrm{CE}$ were assigned $4 ; \mathrm{T}$ and turbidity were assigned 3; TDS and TH were assigned 2; and $\mathrm{Cl}^{-}$ was assigned 1. This information is present in Table 1. In the second step, the results of each variable obtained previously from the ANOVA were examined independently to scrutinize the specific weights of the parameters according to a range of tolerance $(\mathrm{Pi}) . \mathrm{Pi}=1$ was assigned to the variables with values in the ideal ranges while values outside the ideal range were given $\mathrm{Pi}=2$. It is important to note that the $\mathrm{Wi}$ and $\mathrm{Pi}$ values used in the present study took into account criteria from previous studies (Table 1). The WQI was calculated with the following Equation (1) suggested by Rubio et al. [28].

$$
\mathrm{WQI}=\frac{\sum_{\mathrm{i}=1}^{\mathrm{n}} \mathrm{Pi} * \mathrm{Wi}}{\sum_{\mathrm{i}=1}^{\mathrm{n}} \mathrm{Pi}} \mathrm{K}
$$

where:

$\mathrm{WQI}=$ water quality index.

$\mathrm{Wi}=$ specific weight of each variable (1-4).

Table 1. Value assigned for water quality parameters.

\begin{tabular}{|c|c|c|c|c|c|}
\hline Parameters & Units & $\mathbf{W i}^{*}$ & $\mathbf{P i}^{* *}$ & Range Tolerance & References \\
\hline \multirow[t]{3}{*}{ pH } & - & 4 & 1 & $6.5-8.5$ & {$[18,41,42]$} \\
\hline & & & 2 & $<6.5$ & \\
\hline & & & 2 & $>8.5$ & \\
\hline \multirow[t]{3}{*}{ EC } & $\mu \mathrm{S} \cdot \mathrm{cm}^{-1}$ & 4 & 1 & $250-500$ & {$[43,44]$} \\
\hline & & & 2 & $<250$ & \\
\hline & & & 2 & $>500$ & \\
\hline \multirow[t]{3}{*}{ DO } & $\mathrm{mg} \cdot \mathrm{L}^{-1}$ & 4 & 1 & $5-7$ & {$[9,41]$} \\
\hline & & & 2 & $<5$ & \\
\hline & & & 2 & $>7$ & \\
\hline \multirow[t]{3}{*}{$\mathbf{T}$} & ${ }^{\circ} \mathrm{C}$ & 3 & 1 & $20-25$ & {$[44,45]$} \\
\hline & & & 2 & $<20$ & \\
\hline & & & 2 & $>25$ & \\
\hline \multirow[t]{3}{*}{ Turbidity } & NTU & 3 & 1 & $5-10$ & {$[18,42,46]$} \\
\hline & & & 2 & $<5$ & \\
\hline & & & 2 & $>5$ & \\
\hline \multirow[t]{3}{*}{ TDS } & $\mathrm{mg} \cdot \mathrm{L}^{-1}$ & 2 & 1 & $120-500$ & {$[17,47]$} \\
\hline & & & 2 & $<120$ & \\
\hline & & & 2 & $>500$ & \\
\hline \multirow[t]{3}{*}{ TH } & $\mathrm{mg} \cdot \mathrm{L}^{-1}$ & 2 & 1 & $150-300$ & {$[17,23]$} \\
\hline & & & 2 & $<150$ & \\
\hline & & & 2 & $>300$ & \\
\hline \multirow[t]{3}{*}{$\mathrm{Cl}^{-}$} & $\mathrm{mg} \cdot \mathrm{L}^{-1}$ & 1 & 1 & $250-300$ & {$[42,46]$} \\
\hline & & & 2 & $<250$ & \\
\hline & & & 2 & $>300$ & \\
\hline
\end{tabular}

${ }^{*}$ Wi (Specific weight), ${ }^{* *} \mathrm{Pi}$ (Range tolerance). 
$\mathrm{Pi}=$ assigned value to each variable in base to a tolerance result (1-2).

$\mathrm{K}=$ constant $(1 ; 0.75 ; 0.50)$.

$\mathrm{K}$ represents a constant according to the level of contamination when the sample was taken. A value of one was assigned to clear water without apparent contamination; 0.75 to water with a low level of turbidity from nonnatural processes; and 0.50 to contaminated water. According to this system the samples obtained from March to June were assigned a value of one, the value of 0.50 those obtained from July to October were assigned 0.50; and those from November to February were assigned 0.75 .

The calculated WQIs were then classified according to the following range: $>2.5$ were excellent quality water; 2.0 to 2.5 good quality water; and $<2.0$ poor quality water.

\section{Results and Discussion}

Table 2 shows the descriptive statistics of the eight variables during the sampling period. The value of the coefficient of variation (CV) demonstrates the heterogeneous concentration during the evaluation period. This variability can be explained by the presence of an atypical drought that the State of Chihuahua experienced, which was considered the most persistent in the last 50 years. Table 3 shows the Pearson's matrix, indicating the correlation between EC and $\mathrm{pH}(\mathrm{r}=0.000)$, as well as $\mathrm{OD}$ and $\mathrm{T}(\mathrm{r}=$ $0.013)$ and SDT $(\mathrm{r}=0.000)$. Coletti et al. [18] reported similar results between $\mathrm{pH}$ and $\mathrm{EC}$, while Jindal and Sharma [8] also noted a positive tendency between SDT and EC, which is comparable to our results. In addition, Rosli et al. [48] pointed out a strong relationship for these variables, explaining that low concentrations of EC indicate low concentrations of soluble salts. Likewise, Lai et al. [49] noted that there is a strong relationship between suspended solids and flooding. Therefore, it can be affirmed that our TDS and EC results could be the re- sult of flooding caused by several tributaries of the dam under study.

\subsection{Physical-Chemical Variables: pH, T, EC, DO, TDS, Turbidity, TH and $\mathrm{Cl}^{-}$}

For $\mathrm{pH}$, the ANOVA detected statistical differences for the month $(\mathrm{P}<0.05)$ and depth $(\mathrm{P}<0.05)$ but not for the month-depth interaction $(\mathrm{P}>0.05)$. The mean was $8.49 \pm$ 0.03 , indicating that water in this ecosystem can be classified as slightly alkaline. This result can be explained by both anthropogenic and natural processes [50,51]. The values in general are within the acceptable limits for potable water [41]. However, from Figure 2(a) it is evident that values were higher in July and August, which may affect the physiology of some aquatic organisms [44]. Logsdon et al. [52], Horvatincic et al. [53] and Srivastava et al. [17] have all noted that precipitation events increase $\mathrm{pH}$ levels in aquatic ecosystems due to the runoff of alkaline substances. On the other hand, low $\mathrm{pH}$ levels were noted in December (Figure 2(a)), which can be explained by the absence of agricultural activities in the region as well as reduced flows of water. Other studies in the same area, like those of Gutierrez et al. [25] and Rubio et al. [28] reported similar values.

The ANOVA for $\mathrm{T}$ showed statistical differences for the month $(\mathrm{P}<0.05)$, the depth $(\mathrm{P}<0.05)$ and the interaction between them $(P<0.05)$. Figure 2(b) shows the interaction effect where the general mean for $\mathrm{T}$ was $19.64^{\circ} \mathrm{C} \pm 0.32^{\circ} \mathrm{C}$. These values behaved consistently for a temperate zone where values are low in winter (December to February) and high in summer. It is well known that variation in temperature affects the availability of dissolved oxygen in aquatic ecosystems, because of which it is essential to know the level of this variable [4,44]. According to Moss [54] aquatic life depends on the stratification produced by temperature and light, so that different species have evolved to survive in specific temperature ranges. In other words, temperature governs the different functions of organisms, as well as the dis-

Table 2. Descriptive statistics of physiochemical parameters at eight sampling sites during the period March 2011 to February 2012 at the Francisco I. Madero Dam in Chihuahua, Mexico.

\begin{tabular}{ccccccccc}
\hline Parameter & Units & Mean & \pm & SE & Min & Max & CV & Quantity \\
\hline pH & - & 8.49 & \pm & 0.03 & 7.63 & 10.65 & 6.59 & 288 \\
EC & $\mu \mathrm{S} \cdot \mathrm{cm}^{-1}$ & 250 & \pm & 1.35 & 190 & 320 & 9.01 & 288 \\
DO & $\mathrm{mg} \cdot \mathrm{L}^{-1}$ & 6.27 & \pm & 0.15 & 1.30 & 12.1 & 38.25 & $264^{*}$ \\
T & ${ }^{\circ}$ & 19.64 & \pm & 0.32 & 11.30 & 30 & 27.93 & 288 \\
Turbidity & $\mathrm{NTU}$ & 32.54 & \pm & 4.22 & 0 & 1120 & 219.90 & 288 \\
TDS & $\mathrm{mg} \cdot \mathrm{L}^{-1}$ & 187.26 & \pm & 0.60 & 170 & 220 & 5.49 & 288 \\
TH & $\mathrm{mg} \cdot \mathrm{L}^{-1}$ & 501.60 & \pm & 5.09 & 240 & 900 & 17.21 & 288 \\
Cl $^{-}$ & $\mathrm{mg} \cdot \mathrm{L}^{-1}$ & 27.38 & \pm & 0.93 & 7.28 & 70.34 & 57.38 & 288 \\
\hline
\end{tabular}

*The parameter DO has only 264 samples because values were not obtained for the first month of sampling; SE: Standard Error; Min: Minimum Value; Max: Maxim Value; CV: Coefficient Variation expressed in \%. 
Table 3. Pearson's correlation matrix for the physicochemical parameters at the Francisco I. Madero Dam in Chihuahua, Mexico.

\begin{tabular}{|c|c|c|c|c|c|c|c|}
\hline Parameter & pH & EC & $\mathbf{T}$ & DO & TDS & TH & $\mathrm{Cl}^{-}$ \\
\hline EC & $0.000^{*}$ & & & & & & \\
\hline $\mathbf{T}$ & $0.001^{*}$ & $0.000^{*}$ & & & & & \\
\hline DO & 0.085 & 0.463 & $0.013^{*}$ & & & & \\
\hline TDS & $0.000^{*}$ & $0.000^{*}$ & $0.000^{*}$ & $0.000^{*}$ & & & \\
\hline TH & 0.109 & $0.000^{*}$ & $0.000^{*}$ & 0.116 & $0.020^{*}$ & & \\
\hline $\mathrm{Cl}^{-}$ & $0.000^{*}$ & $0.000^{*}$ & $0.000^{*}$ & $0.000^{*}$ & $0.000^{*}$ & $0.000^{*}$ & \\
\hline Turbidity & 0.090 & $0.001^{*}$ & 0.418 & 0.071 & 0.051 & $0.000^{*}$ & $0.015^{*}$ \\
\hline
\end{tabular}

${ }^{*}$ Correlation is significant at the level of 0.05 .

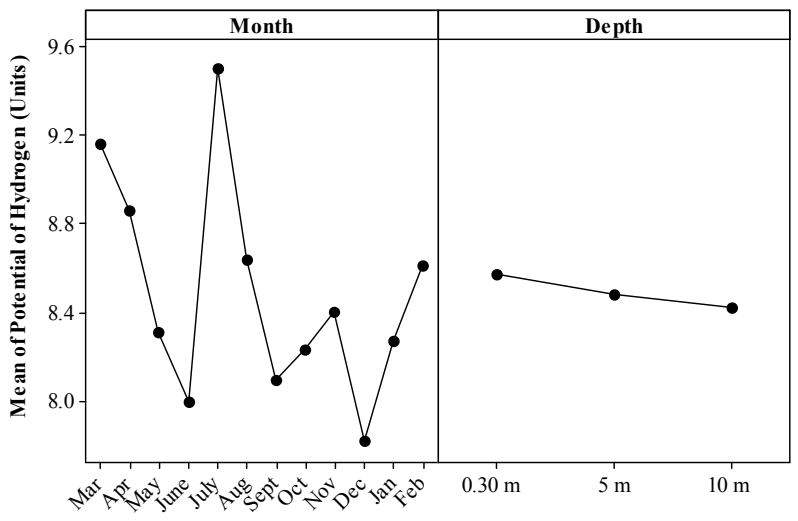

(a)

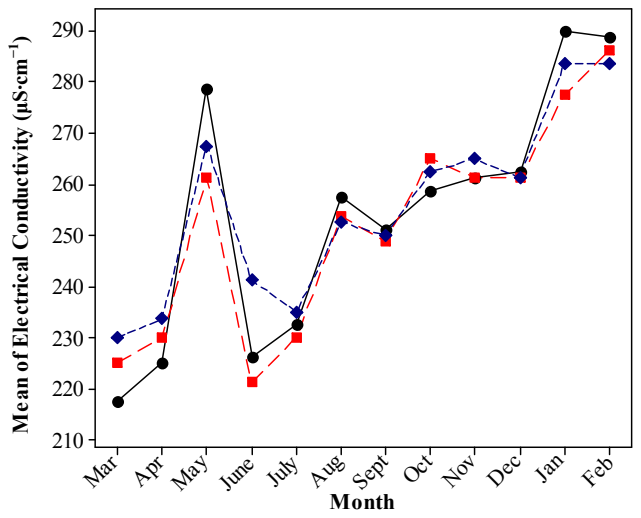

(c)

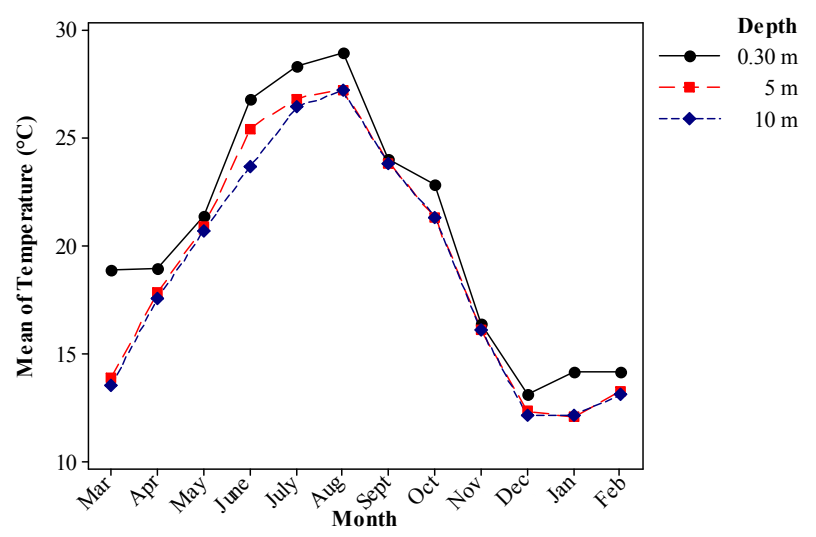

(b)

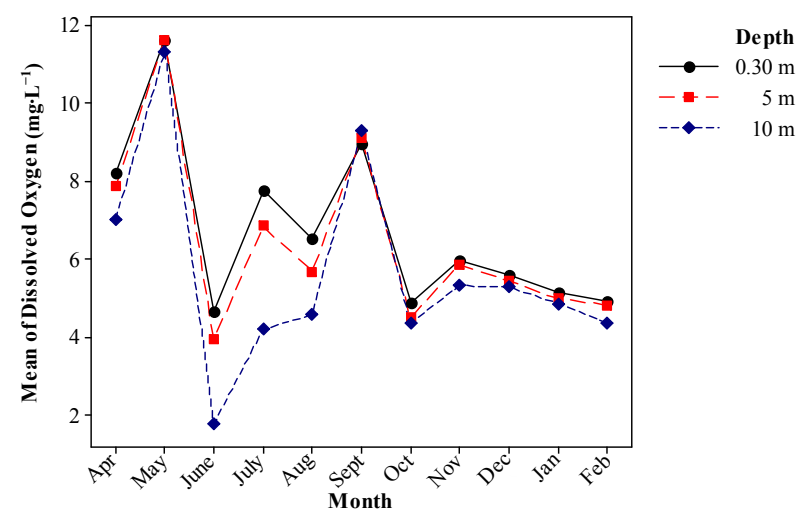

(d)

Figure 2. Levels of the parameters pH, T, EC and DO in water samples obtained in the Francisco I. Madero Dam in Chihuahua, Mexico.

tribution of their populations [55]. For instance, a drastic change in temperature can cause hepatic or skin problems in species like Oreochromis spp., while small changes in temperature might origin species succession [56].

There were statistical differences for the variable EC for the month $(\mathrm{P}<0.05)$ and for the month-depth interaction $(\mathrm{P}<0.05)$ but not for the sampling depth $(\mathrm{P}>0.05)$. The average was $250 \pm 1.35 \mu \mathrm{S} \cdot \mathrm{cm}^{-1}$ which is below the standard limits proposed by Srebotnjak et al. [44] of $<500 \mu \mathrm{S} \cdot \mathrm{cm}^{-1}$. Figure 2(c) presents the interaction effect. These results can be explained by the drought that oc- curred this year. Miyamoto et al. [57], Kannel et al. [58] and Sanchez et al. [20] have noted that during droughts in arid zones the accumulation of salts and other contaminates increase and as a consequence EC levels also increase. Moreover, it is well documented that EC values are good indicators that have been used to calculate WQI, especially where high EC values indicate heavy levels of inorganic contamination [2,3,28].

The DO variable was different for the month $(\mathrm{P}<$ 0.05), depth $(\mathrm{P}<0.05)$ and the interaction between month and depth $(\mathrm{P}<0.05)$. Figure $2(\mathbf{d})$ shows the interaction 
effect. It can be from the figure that OD levels varied according to depth, which is due to variations in temperature [44]. The average was $6.27 \pm 0.15 \mathrm{mg} \cdot \mathrm{L}^{-1}$, which means that in relation to this variable the water is acceptable and within the permitted range of $5-7 \mathrm{mg} \cdot \mathrm{L}^{-1}$ [9]. Additionally, the values indicate that water in this ecosystem can maintain aerobic organisms and plants with a good auto depurative capacity [59]. It is important to keep in mind that DO is an important indicator of the health of an ecosystem because of its effect on aquatic life and physical-biological processes $[13,48,60]$. OD levels are higher after precipitation events because of organic matter transported by runoff from agricultural and animal production activities in the higher areas of the watershed.

The difference in TDS was statistically significant for the month and the interaction between the month and depth $(\mathrm{P}<0.05)$ but not for the depth $(\mathrm{P}>0.05)$. In Figure 3(a) it can be noted the interaction and the values were in a range of $175.41-199.98 \mathrm{mg} \cdot \mathrm{L}^{-1}$ indicating that the water is acceptable because it is within the permissible limits of $120-500 \mathrm{mg} \cdot \mathrm{L}^{-1}$ [17]. Khalil et al. [61] specified that TDS accounts for both organic and inorganic matter present in water. Our results are lower than those

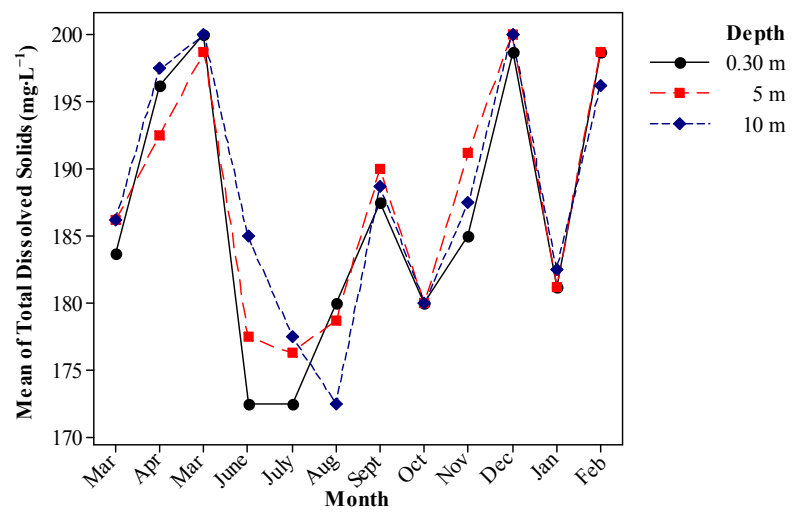

(a)

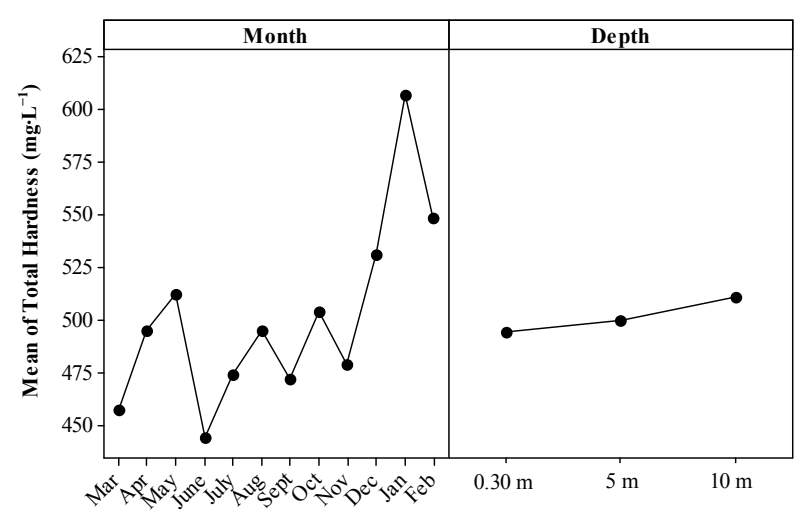

(c) reported by Contreras [62] who found an average TDS of $612 \mathrm{mg} \cdot \mathrm{L}^{-1}$ in the Luis L. Leon Dam, which is located downstream from the dam in our study. Turbidity was statistically different for the month and depth $(\mathrm{P}<0.05)$ but not for the interaction $(\mathrm{P}>0.05)$. The average was $32.54 \pm 4.22 \mathrm{NTU}$ and the highest values were during and after the rainy season. However, in December there were higher levels that can be explained by winter precipitation levels. On the right side of Figure 3(b) an increase can be noted due to depth that can be explained by precipitated solids. Several authors have noted that runoff increases turbidity in aquatic ecosystems, and as a consequence, raises contamination levels [5,63-65]. Hurley et al. [4] established that the variable of turbidity was of relevance in calculating WQI for similar studies.

The ANOVA for TH only found statistical differences for the sampling month $(\mathrm{P}<0.05)$, where the general average was $501.60 \pm 5.09 \mathrm{mg} \cdot \mathrm{L}^{-1}$. The maximum level was in December with $606.66 \pm 18.32 \mathrm{mg} \cdot \mathrm{L}^{-1}$, while the lowest level was in June with $444.16 \pm 8.51 \mathrm{mg} \cdot \mathrm{L}^{-1}$. Figure 3(c) shows the $\mathrm{TH}$ found in this study. The sampled waters can be considered very hard because the ideal levels are in a range of $150-300 \mathrm{mg} \cdot \mathrm{L}^{-1}$ [23]. With respect to $\mathrm{Cl}^{-}$concentrations, the ANOVA only found sta-

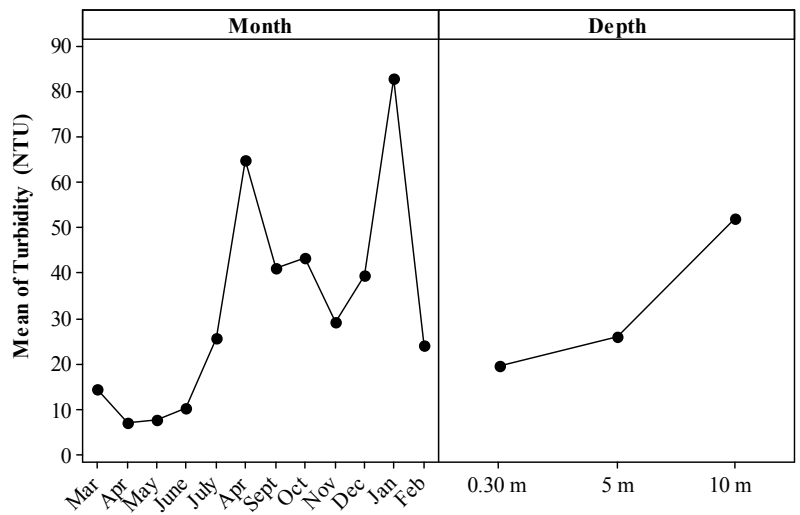

(b)

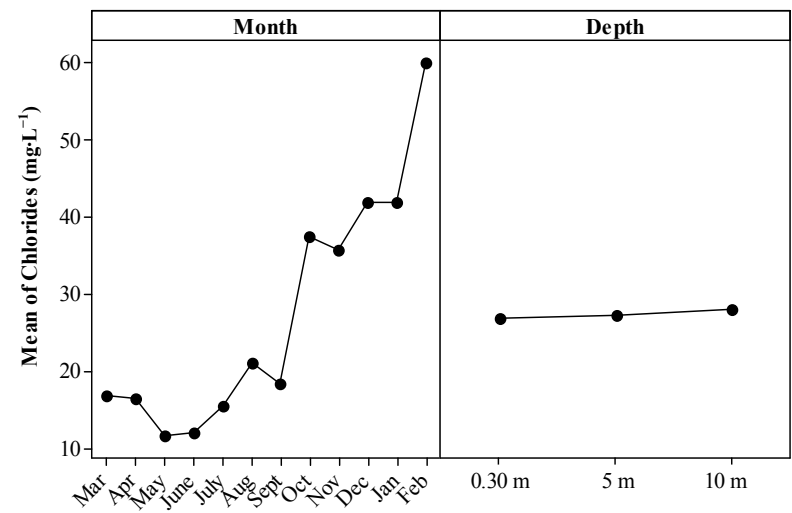

(d)

Figure 3. Levels of the parameters TDS, turbidity, TH and $\mathrm{Cl}^{-}$in water samples from the Francisco I. Madero Dam in Chihuahua, Mexico. 
tistical differences for the sampling month $(\mathrm{P}<0.05)$, the effect of which is shown in Figure 3(d), where the general average is $27.38 \pm 0.93 \mathrm{mg} \cdot \mathrm{L}^{-1}$. The highest concentration was in February 2012 with $60.03 \pm 1.43 \mathrm{mg} \cdot \mathrm{L}^{-1}$, while the lowest was in May with $11.62 \pm 0.62 \mathrm{mg} \cdot \mathrm{L}^{-1}$. Jindal and Sharma [8] noted that $\mathrm{Cl}^{-}$levels are affected by precipitation because in some cases rain contains acids or high concentrations of salts. Previous research in the same area found similar values for this variable [28, 66]. Our results indicate a good level of water for this variable given that the recommended limit is $250 \mathrm{mg} \cdot \mathrm{L}^{-1}$ [46].

\subsection{Water Quality Index (WQI)}

The WQIs were different among the sampled months, with a general mean of 2.1, indicating that water from the dam can be considered acceptable. Nevertheless, during July, August and September the water was poor because the index was below 2.0. These values were observed in the rainy season, despite the severe drought affecting northern Mexico [67]. In other words, the best WQI levels were noted in the spring while the worst were in summer and autumn. The results are shown in Table 4 and Figures 4(a) and (b). It is important to note that variables assigned with higher Wi values presented high levels during the rainy season while DO was below the permissible limits [41]; hence, a certain level of contamination was noted [68]. Our results clearly show low water quality during the summer because in the sense that variables outside the Pi range are vulnerable, the water quality is low. Qian et al. [11] found an increase in the physicalchemical variables during the rainy season, and consequently low levels of water quality. This is because some rain is acidic or can have more diluted contaminants [27]. Varnosfaderany et al. [50] estimated a WQI for an ecosystem of an arid zone and found lower levels in August, which they attributed to agricultural activities that increase FC and DBO concentrations in water. In another study He et al. [16] developed a WQI in Victoria, Australia for different watersheds of semiarid areas using DO, $\mathrm{FC}$ and $\mathrm{pH}$ as the main variables. Their results showed seven watersheds as "very poor", one as "poor", one as "regular" and only one as "excellent". They attributed their results to spatial and temporal variability. Srivastava et al. [17] reported a decline in WQI values for the Mahi River in India before and after the rainy season. This effect was explained due to runoff that comes from agricultural and industrial zones.

Rubio et al. [28] developed a WQI for the Luis L. Leon Dam located in northern Mexico using physical and chemical variables. According to the calculated WQI values, these researchers classified the water as "poor" in August and November, which is the rainy season in that

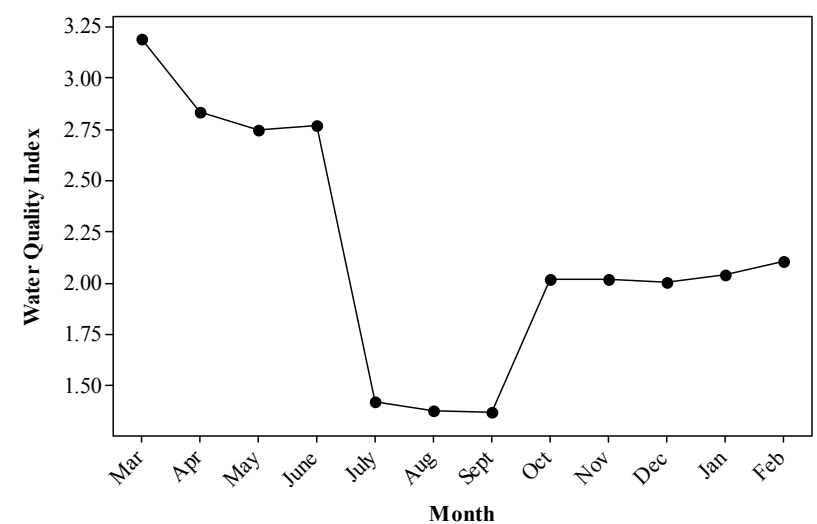

(a)

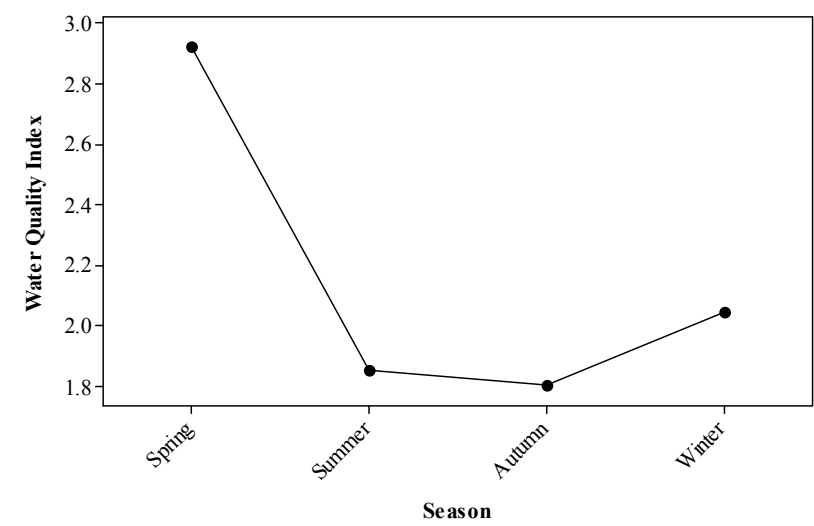

(b)

Figure 4. WQI values calculated over several months and seasons at the Francisco I. Madero Dam in Chihuahua, Mexico.

Table 4. WQI values per months at the Francisco I. Madero Dam from March 2011 to February 2012.

\begin{tabular}{ccc}
\hline Month & WQI $^{*}$ & Water Quality \\
\hline March & 3.19 & Excellent \\
April & 2.84 & Excellent \\
May & 2.74 & Good \\
June & 2.77 & Good \\
July & 1.42 & Poor \\
August & 1.38 & Poor \\
September & 1.37 & Poor \\
October & 2.02 & Good \\
November & 2.02 & Good \\
December & 2.00 & Good \\
January & 2.04 & Good \\
February & 2.10 & Good \\
Average & 2.15 & Good
\end{tabular}

*WQI value was determined based on the methodology employed by Rubio et al. [28].

region. It is clear that "poor" water indicates an aquatic ecosystem with high levels of variables such as turbidity and organic matter that can represent a risk for the envi- 
ronment and human health [18].

There is strong evidence that precipitation directly affects water in aquatic ecosystems [17]. In addition, variations in WQI values are explained by both specific and general contamination, such as mining operations, industry, agriculture, livestock production and domestic activties that in turn affect water bodies $[1,9,65]$. Agriculture activities in particular play an important role in lowering WQI values, especially in areas where practices are inappropriate.

Our results show that the best water quality was in March and April 2011 when the water was classified as excellent (Table 4). Rejith et al. [69] also reported high WQI values in the spring. Our results demonstrate that WQI values increased in the rainy season and then declined once more to be stabilized in autumn and winter. It is important to note that in December there were few precipitation events, which explains the increase in $\mathrm{pH}$ levels and turbidity and as a consequence the WQI value. During the period of October 2011 to March 2012, activities in ID-005 were low and consequently runoff was also low, resulting in better quality surface waters. Wanda et al. [23] found acceptable levels in water during winter in an African ecosystem, while Rubio et al. [28] also reported good levels of water in winter.

\section{Conclusion}

Most parameters increased during the rainy season. The variables of turbidity and TH were beyond the permissible limits according to Mexican and international standards. The calculated WQI determined excellent water quality for the spring, good quality for autumn and winter and poor for summer. Our results show that the water of this ecosystem of this ecosystem can be used without any problem for ecological purposes as well as for fishing, agriculture and livestock production. It is highly recommend to continue monitoring water and to employ other methodologies like the WQI using additional variables.

\section{REFERENCES}

[1] S. M. Liou, S. L. Lo and S. H. Wang, "A Generalized Water Quality Index for Taiwan," Environmental Monitoring and Assessment, Vol. 96, No. 1-3, 2004, pp. 35-52. http://dx.doi.org/10.1023/B:EMAS.0000031715.83752.a1

[2] A. Gibrilla, E. K. P. Bam, D.Adomako, S. Ganyaglo, S. Osae, T. T. Akiti, S. Kebede, E. Achoribo, E. Ahialey, G. Ayanu and E. K. Agyeman, "Application of Water Quality Index (WQI) and Multivariate Analysis for Groundwater Quality Assessment of the Birimian and Cape Coast Granitoid Complex: Densu River Basin of Ghana," Water Quality, Exposure, and Health, Vol. 3, No. 2, 2011, pp. 63-78. http://dx.doi.org/10.1007/s12403-011-0044-9

[3] A. Lumb, T. C. Sharma and J. F. Bibeault, "A Review of Genesis and Evolution of Water Quality Index (WQI) and
Some Future Directions," Water Quality Exposure and Health, Vol. 3, No. 1, 2011, pp. 11-24.

[4] T. Hurley, R. Sadiq and A. Mazumber, "Adaptation and Evaluation of the Canadian Council of Ministers of the Environmental Water Quality Index (CCME WQI) for Use as an Effective Tool to Characterize Drinking Source Water Quality," Water Research, Vol. 46, No. 11, 2012, pp. 3544-3552.

http://dx.doi.org/10.1016/j.watres.2012.03.061

[5] H. Gharibi, N. H. Sowlat, A. H. Mahvi, H. Mahmoudzadeh, H. Arabalibeik, M. Keshavarz, N. Karimzadeh and G. Hassani, "Development of a Dairy Cattle Drinking Water Quality Index (DCWQI) Based on Fuzzy Inference Systems," Ecological Indicators, Vol. 20, 2012, pp. 228-237. http://dx.doi.org/10.1016/j.ecolind.2012.02.015

[6] Z. Ma, X. Song, R. Wan and L. Gao, "A Modified Water Quality Index for Intensive Shrimp Ponds of Litopenaeusvannamei," Ecolological Indicators, Vol. 24, 2013, pp. 287-293.

[7] J. E. Sedeño-Diaz and E. Lopez-Lopez, "Water Quality in the Rio Lerma, Mexico: An Overview of the Last Quarter of the Twentieth Century," Water Resources Management, Vol. 21, No. 10, 2007, pp. 1797-1812. http://dx.doi.org/10.1007/s11269-006-9128-x

[8] R. Jindal and C. Sharma, "Studies on Water Quality of Sutlej River around Ludhiana with Reference to Physicochemical Parameters," Environmental Monitoring and Assessment, Vol. 174, No. 1-4, 2011, pp. 417-425.

[9] N. M. Gazzaz, M. K. Yusoff, A. Z. Aris, H. Juahir and M. F. Ramli, "Artificial Neutral Network Modeling of the Water Quality Index for Kinta River (Malaysia) Using Water Quality Variables as Predictors," Marine Pollution Bulletin, Vol. 64, No. 11, 2012, pp. 2409-2420. http://dx.doi.org/10.1016/j.marpolbul.2012.01.032

[10] R. K. Horton, “An Index Number System for Rating Water Quality," Journal of the Water Pollution Control Federation, Vol. 37, No. 3, 1965, pp. 300-306.

[11] Y. Qian, K. W. Migliaccio, Y. Wan and Y. Li, "Surface Water Quality Evaluation Using Multivariate Methods and a New Water Quality Index in River Lagoon, Florida," $\mathrm{Wa}$ ter Resources Research, Vol. 43, No. 8, 2007, pp. 1-10. http://dx.doi.org/10.1029/2006WR005716

[12] A. H. M. J. Alobaidy, H. S. Abid and B. K. Maulood, "Application of Water Quality Index for Assessment of Dokan Lake Ecosystem, Kurdistan Region, Iraq," Journal of Water Resource and Protection, Vol. 2, No. 9, 2010, pp. 792-798. http://dx.doi.org/10.4236/jwarp.2010.29093

[13] A. J. Dhembare, J. Dhumal and I. I. Mujawar, "Evaluation of Water Quality Index for Drinking from Ashvi Dam Water Sangamner, Ahmednagar, Maharashtra," Indian Streams Research Journal, Vol. 2, No. 4, 2012, pp. 1-5.

[14] T. Y. Stigter, L. Ribeiro and A. M. M. Carvalho Dill, “Application of a Groundwater Quality Index as an Assessment and Communication Tool in Agro-Environmental Policies-Two Portuguese Case Studies," Journal of Hydrology, Vol. 327, No. 3, 2006, pp. 578-591. http://dx.doi.org/10.1016/j.jhydrol.2005.12.001

[15] F. D. S. Simoes, A. B. Moreira, M. C. Bisinoti, S. M. N. Gimenez and M. J. S. Yabe, "Water Quality Index as a 
Simple Indicator of Aquaculture Effects on Aquatic Bodies," Ecological Indicators, Vol. 8, No. 5, 2008, pp. 476484. http://dx.doi.org/10.1016/j.ecolind.2007.05.002

[16] J. He, Y. Zhang and G. Huang, "Exceptional Object Analysis for Finding Rare Environmental Events from Water Quality Datasets," Neurocomputing, Vol. 92, 2012, pp. 69-77. http://dx.doi.org/10.1016/j.neucom.2011.08.036

[17] P. K. Srivastava, S. Mukherjee, M. Gupta and S. K. Singh, "Characterizing Monsoonal Variation on Water Quality Index of River Mahi in India Using Geographical Information System," Water Quality Exposure and Health, Vol. 2, No. 3-4, 2011, pp. 193-203. http://dx.doi.org/10.1007/s12403-011-0038-7

[18] C. Almeida, S. O. Gonzalez, M. Mallea and P. Gonzalez, "A Recreational Water Quality Index Using Chemical, Physical and Microbiological Parameters," Environmental Science and Pollution Research International, Vol. 19, No. 8, 2012, pp. 3400-3411. http://dx.doi.org/10.1007/s11356-012-0865-5

[19] C. Coletti, R. Testezlaf, T. A. P. Ribeiro, R. T. G. de Souza and D. A. Peraira, "Water Quality Index Using Multivariate Factorial Analysis," Revista Brasileira de Engenharia Agricola e Ambiental, Vol. 14, No. 5, 2010, pp. 517-522.

http://dx.doi.org/10.1590/S1415-43662010000500009

[20] E. Sanchez, M. F. Colmenero, J. Vicente, A. Rubio, M. G. Garcia, L. Travieso and R. Borja, "Use of the Water Quality Index and Dissolved Oxygen Deficit as Simple Indicators of Watersheds Pollution," Ecological Indicators, Vol. 7, No. 2, 2007, pp. 315-328.

http://dx.doi.org/10.1016/j.ecolind.2006.02.005

[21] C. G. Cude, "Oregon Water Quality Index a Tool for Evaluating Water Quality Management Effectiveness 1," JAWRA Journal of American Water Resources Association, Vol. 37, No. 1, 2001, pp. 125-137. http://dx.doi.org/10.1111/j.1752-1688.2001.tb05480.x

[22] R. Nikoo, R. Kerachian, S. Malakpour-Estalaki, S. N. Bashi-Azghadi and M. M. Azimi-Ghadikolaee, "A Probabilistic Water Quality Index for River Water Quality Assessment: A Case Study," Environmental Monitoring and Assessment, Vol. 181, No. 1-4, 2011, pp. 465-478. http://dx.doi.org/10.1007/s10661-010-1842-4

[23] E. M. M. Wanda, L. C. Gulula and G. Phiri, "Determination of Characteristics and Drinking Water Quality Index in Mzuzu City, Northern Malawi," Physics and Chemistry of the Earth Parts $A / B / C$, Vol. 50-52, 2012, pp. 92-97. http://dx.doi.org/10.1016/j.pce.2012.09.004

[24] M. Kelly, "El Rio Conchos: Un Informe Preliminar," 2001. http://www.texascenter.org/publications/spaconchos.pdf

[25] R. Gutierrez, H. Rubio-Arias, R. Quintana, J. A. Ortega and M. Gutierrez, "Heavy Metals in Water of the San Pedro River in Chihuahua, Mexico and Its Potential Health Risk," International Journal of Environmental Research and Public Health, Vol. 5, No. 2, 2008, pp. 91-98. http://dx.doi.org/10.3390/ijerph5020091

[26] C. Holguin, A. H. Rubio, M. E. Olave, R. Saucedo, M. Gutierrez and R. Bautista, "Calidad del Agua del Rio Conchos en la Region de Ojinaga, Chihuahua; Parametro- sfisicoquimicos, Metales y Metaloides," Universidad y Ciencia, Vol. 22, No. 1, 2006, pp. 51-64.

[27] H. Rubio-Arias, C. Quintana, J. Jimenez-Castro, R. Quintana and M. Gutierrez, "Contamination of the Conchos River in Mexico: Does It Pose a Health Risk to Local Residents?" International Journal of Environmental Research and Public Health, Vol. 7, No. 5, 2010, pp. 20712084. http://dx.doi.org/10.3390/ijerph7052071

[28] H. Rubio-Arias, M. Contreras-Caraveo, R. M. Quintana, R. A. Saucedo-Teran and A. Pinales-Munguia, "An Overall Water Quality Index for a Man-Made Aquatic Reservoir in Mexico," International Journal of Environmental Research and Public Health, Vol. 9, No. 5, 2012, pp. 1687-1698. http://dx.doi.org/10.3390/ijerph9051687

[29] R. Gutierrez, R. Quintana, H. Rubio, J. Ortega and C. Pinedo, "Indice de Calidad del Agua en la Cuenca Baja del Rio San Pedro, Chihuahua, Mexico," Revista Latinoamericana de Recursos Naturales, Vol. 4, No. 2, 2008, pp. 108-115.

[30] SAGARPA, "Hidrografia del Estado de Chihuahua. Secretaria de Agricultura, Ganaderia, Desarrollo Rural, Pesca y Alimentacion," 2003.

[31] CONAGUA, "Comision Nacional del Agua. Subdireccion General," 2010.

http://www.conagua.gob.mx/CONAGUA07/Contenido/D ocumentos/Capitulo_1.pdf

[32] INEGI, "Instituto Nacional de Estadistica y Geografia. Marco Geoestadistico Municipal-Version 3.1,” 2005.

[33] NMX-AA-014-1980, "Norma Mexicana. Cuerpos Receptores-Muestreo," 1980.

[34] NMX-007-SCFI-2000, "Norma Mexicana. Analisis de Agua-Determinacion de la Temperatura en Aguas Naturales, Residuales, Residuales y Residuales Tratadas-Metodos de Prueba," 2000.

[35] NMX-AA-008-SCFI-2000, "Norma Mexicana. Analisis de Agua-Determinacion del pH-Metodo de Prueba," 2000.

[36] NOM-AA-093-SCFI-2000, "Norma Mexicana. Analisis de Agua-Determinacion de la Conductividad Electrolitica-Metodode Prueba. Secretaria de Comercio y Fomento Industrial," 2000.

[37] NMX-AA-012-SCFI-2001, "Norma Mexicana. Analisis de Agua-Determinacion de Oxigeno Disuelto en Aguas Naturales, Residuales y Residuales Tratadas-Metodo de Prueba, Secretaria de Comercio y Fomento Industrial," 2001.

[38] NMX-AA-038-SCFI-2001, "Norma Mexicana. Analisis de Agua-Determinacion de Turbidez en Aguas Naturales, Residuales y Residuales Tratadas-Metodo de Prueba. Secretaria De Comercio y Fomento Industrial," 2001.

[39] NMX-AA-072-SCFI-2001, "Norma Mexicana. Analisis de Agua-Determinacion de Dureza Total en Aguas Naturales, Residuales y Residuales Tratadas-Metodo de Prueba. Secretaria De Comercio y Fomento Industrial," 2001.

[40] NMX-AA-073-SCFI-2001, "Norma Mexicana. Analisis de Agua-Determinacion de Cloruros Totales en Aguas Naturales, Residuales y Residuales Tratadas-Metodo de 
Prueba. Secretaria De Comercio y Fomento Industrial," 2001.

[41] WHO, "International Standards for Drinking Water," World Health Organization, Geneva, 1992.

[42] NHMRC, "National Water Quality Management Strategy. Australian Drinking Water Guidelines 6-2011," 2012. http://www.nhmrc.gov.au/guidelines/publications/eh52

[43] D. L. Sorensen, M. McCarthy, E.J. Middlebrooks and D. B. Porcella, "Suspended and Dissolved Solids Effects on Freshwater Biota: A Review. US Environmental Protection Agency, EPA-600/3-77-042," 1977.

[44] T. Srebotnjak, G. Carr, A. de Sherbinin and C. Rickwood, "A Global Water Quality Index and Hot-Deck Imputation of Missing Data," Ecological Indicators, Vol. 17, 2012, pp. 108-119. http://dx.doi.org/10.1016/j.ecolind.2011.04.023

[45] Lenntech, "Water Treatment Solution," 2013. http://www.lenntech.es/faq-quimica-agua.htm

[46] NOM-127-SSA1-1994, "Norma Mexicana. Salud Ambiental, Agua Para Uso y Consumo Humano-Limites Permisibles de Calidad y Tratamientos a Que Debe Someterse el Agua Para su Potabilizacion. Secretaria de Salud," 1994.

[47] F. Fuentes and A. Massol-Deya, "Manual de Ecologia Microbiana. Departamento de Biologia. Universidad de Puerto Rico," 2002.

http://ocw.um.es/ciencias/ecologia/lectura-obligatoria-1/p 1-intro.pdf

[48] N. Rosli, S. Gandaseca, J. Ismail and M. I. Jailan, "Comparative Study of Water Quality at Different Peat Swamp Forest of Batang Igan, Sibu Sarawak," American Journal of Environmental Science, Vol. 6, No. 5, 2010, pp. 416421. http://dx.doi.org/10.3844/ajessp.2010.416.421

[49] Y. C. Lai, Y. T. Tu, C. P. Yang, R. Y. Surampalli and C. M. Kao, "Development of a Water Quality Modeling System for River Pollution Index and Suspended Solid Loading Evaluation," Journal of Hydrology, Vol. 478, 2013, pp. 89-101.

http://dx.doi.org/10.1016/j.jhydrol.2012.11.050

[50] M. N. Varnosfaderany, N. Mirghaffary, E. Ebrahimi and A. Soffianian, "Water Quality Assessment in an Arid Region Using a Water Quality Index," Water Science \& Technology, Vol. 60, No. 9, 2009, pp. 2319-2327. http://dx.doi.org/10.2166/wst.2009.669

[51] S. Sharma, R. K. R. Yadav, Y. Saini and S. Sharma, "Water Quality Status of Pushkar Lake as a Primary Data for Sustainable Development," South Asian Journal of Tourism and Heritage, Vol. 4, No. 2, 2011, pp. 184-192.

[52] G. S. Logsdon, O. D. Schneider and G. C. Budd, "Hindsight is 20/20: Using History to Avoid Waterborne Disease Outbreaks," Journal of the American Water Works Association, Vol. 96, No. 7, pp. 66-74.

[53] N. Horvatincic, J. L. Brianso, B. Obelic, J. Baresic and I. K. Bronic, "Study of Pollution of the Plitvice Lakes by Water and Sediment Analyses. The Interactions between Sediments and Water," Water, Air, and Soil Pollution: Focus, Vol. 6, No. 5-6, 2006, pp. 111-121. http://dx.doi.org/10.1007/s11267-006-9031-8
[54] B. Moss, "Ecology of fresh Waters, Man and Medium," Blackwell Sciences, Oxford, 1992.

[55] G. Valverde and G. B. Garcia, "Influencia del Peso y la Temperatura Sobre el Consumo de Oxígeno de Rutina del Denton Comun (Dentexdentex Linnaeus 1758)," Aquatic, Vol. 2, No. 21, 2004, pp. 16-23.

[56] A. A. De Ocampo and L. O. Camberos, "Diagnostico del Estres en Peces," Veterinaria Mexico, Vol. 30, No. 4, 1999, pp. 337-344.

[57] S. Miyamoto, L. B. Fenn and D. Swetlik, "Flow of Salts and Trace Elements in the Rio Grande System," Texas Agriculture Experimental Station-Texas Water Resources Institute College Station, Vol. 1, 1995, p. 6160. http://hdl.handle.net/1969.1/6160

[58] P. R. Kannel, S. Lee, Y. S. Lee, S. R. Kanel and S. P. Khan, "Application of Water Quality Indices and Dissolved Oxygen as Indicators for River Water Classification and Urban Impact Assessment," Environmental Monitoring and Assessment, Vol. 132, No. 1-3, 2007, pp. 93110. http://dx.doi.org/10.1007/s10661-006-9505-1

[59] M. V. Sperling, "Principios Basicos do Tratamento de Esgotos," 4th Edition, Universidade Federal de Minas Gerais, Belo Horizonte, 2001.

[60] J. J. Carbajal-Hernandez, L. P. Sanchez-Fernandez, J. A. Carrasco-Ochoa and J. F. Martinez-Trinidad, "Inmediate Water Quality Assessment in Shrimp Culture Using Fuzzy Inference Systems," Expert Systems with Applications, Vol. 39, No. 12, 2012, pp. 10571-10582. http://dx.doi.org/10.1016/j.eswa.2012.02.141

[61] B. Khalil, T. B. M. J. Ouarda and A. St-Hilaire, "Estimation of Water Quality Characteristics at Ungauged Sites Using Artificial Neural Networks and Canonical Correlation Analysis," Journal of Hydrology, Vol. 405, No. 3, 2011, pp. 277-287. http://dx.doi.org/10.1016/j.jhydrol.2011.05.024

[62] C. M. Contreras, "Niveles de Contaminacion en el Agua de la Presa Luis L. Leon (El Granero) en Chihuahua, Mexico," Master's Thesis, Autonomous University of Chihuahua, Chihuahua, 2012.

[63] P. G. Whitehead, D. Wilby, R. W. Battarbee, M. Kernan and A. J. Wade, "A Review of the Potential Impacts of Climate Change on Surface Water Quality," Hydrological Sciences Journal, Vol. 54, No. 1, 2009, pp. 101-123. http://dx.doi.org/10.1623/hysj.54.1.101

[64] S. Gandaseca, N. Rosli, J. Ngayop and C. I. Arianto, "Status of Water Quality Based on the Physico-Chemical Assessment on River Water at Wildlife Sanctuary Sibuti Mangrove Forest, Miri Sarawak," American Journal of Environmental Sciences, Vol. 7, No. 3, 2011, pp. 269275. http://dx.doi.org/10.3844/ajessp.2011.269.275

[65] W. Ocampo-Duque, C. Osorio, C. Piamba, M. Schuhmacher and J. L. Domingo, "Water Quality Analysis in Rivers with Non-Parametric Probability Distributions and Fuzzy Inference Systems: Application to the Cauca River Colombia," Environment International, Vol. 52, 2013, pp. 17-28. http://dx.doi.org/10.1016/j.envint.2012.11.007

[66] M. Gutierrez and E. Carreon-Hernandez, "Salinidad en el Bajo Rio Conchos: Aportes y Tendencias," TERRA Lati- 
noamericana, Vol. 22, No. 4, 2004, pp. 499-506.

[67] CONAGUA, "Comision Nacional del Agua. Reporte Anual del Clima en Mexico 2011. Servicio Meteorologico Nacional. Gerencia de Meteorologiay Climatologia, Subgerencia de Pronóstico a Mediano y Largo Plazo,” 2011. http://smn.cna.gob.mx/climatologia/analisis/reporte/Anua 12011.pdf

[68] J. Yisa and T. Jimoh, “Analytical Studies on Water Quali- ty Index of River Landzu," American Journal of Applied Sciences, Vol. 7, No. 4, 2010, pp. 453-458. http://dx.doi.org/10.3844/ajassp.2010.453.458

[69] P. G. Rejith, S. P. Jeeva, H. Vijith, M. Sowmya and A. A. Hatha, "Determination of Groundwater Quality Index of a Highland Village of Kerala (India) Using Geographic Information System," Journal of Environmental Health, Vol. 71, No. 10, 2009, pp. 51-58. 